\title{
SER LIBRES BAJO EL PODER DEL REY. EL REPUBLICANISMO Y CONSTITUCIONALISMO DE BARTOLOMÉ DE LAS CASAS
}

\author{
Francisco Quijano \\ Universidad Nacional Autónoma de México
}

\section{INTRODUCCIÓN}

B artolomé de Las Casas (c. 1484-1566) es uno de los autores más conocidos en la historia del pensamiento político hispanoamericano. La crítica que dirigió contra la conquista de América y su apología de los pueblos indígenas han sido ampliamente recuperadas y discutidas, desde el momento de su enunciación hasta nuestros días. Sin embargo, los fundamentos de su pensamiento político han sido poco explorados por la historiografía. En el presente artículo busco dar cuenta de algunos de los principios y presupuestos sobre los cuales Las Casas sustentó, en su madurez intelectual, sus escritos políticos. En particular analizo la manera en que concibió tres cuestiones medulares: el origen

Fecha de recepción: 27 de noviembre de 2014 Fecha de aceptación: 5 de enero de 2015 
y la legitimidad del poder, los límites de la autoridad y la libertad. ${ }^{1}$

$\mathrm{Al}$ analizar el pensamiento político de Las Casas, particularmente en sus últimos tratados, se observa que uno de los principales problemas que buscó resolver fue el de conciliar el poder y la libertad. Esta preocupación, a mi juicio, responde a dos espacios de conflicto y controversia que configuraron el ámbito político e intelectual del mundo hispánico durante el siglo xvi: por un lado, el problema de la conquista y dominio de las Indias y, por el otro, la tensión generada entre las acciones centralizadoras de la corona y el poder de las ciudades y otras corporaciones que buscaron mantener sus privilegios y autonomía dentro del orden político compuesto o plurijurisdiccional que caracterizó a la Monarquía hispánica. ${ }^{2}$ En cuanto al primero de ellos, Las Casas

${ }^{1}$ Entre la enorme cantidad de trabajos sobre la vida y el pensamiento de Las Casas se encuentran los estudios de Hanke y Giménez FernánDez, Bartolomé de Las Casas, 1474-1566; Hanke, "Bartolomé de Las Casas, historiador", pp. ix-lxxxviii; PARIsh, Las Casas as a Bishop; Pennington, "Bartholome de Las Casas", pp. 149-161; Bataillon, Estudios sobre Bartolomé de Las Casas. Junto a ellos, se encuentran los estudios introductorios a las ediciones críticas de sus obras y los capítulos referentes al autor en obras generales sobre el pensamiento hispano y novohispano que por razones de espacio no referiré aquí. Una síntesis bibliográfica actualizada se puede consultar en NAIR, "Contra imperio", pp. 11-30. Cabe señalar que algunos autores han abordado los fundamentos del pensamiento político de Las Casas realizando importantes contribuciones, pero lo han hecho desde una perspectiva jurídica o filosófica, o bien se centran más en su dimensión religiosa. Véanse Cárdenas Bunsen, Escritura y derecho canónico; Queraltó, El pensamiento filosófico-politico; Valdivia, Llamado a la misión pacífica; ВеUсHOt, Los fundamentos. ${ }^{2}$ Sobre las características del orden jurídico político de la Monarquía véanse Fernández Albaladejo, Fragmentos de monarquía; Mazín y Ruiz Ibáñez (eds). Las Indias Occidentales; Cardim, Herzog, Ruiz 
se cuestionó sobre las condiciones para que el rey de España pudiera ejercer un gobierno legítimo sobre América, sin que ello implicara la pérdida de libertad de los indígenas y de sus reinos y señoríos. En cuanto al segundo, sin desafiar la legitimidad del poder monárquico, analizó sus características y postuló sus límites en relación con los ciudadanos y a las ciudades o repúblicas constituidas por éstos. En este artículo veremos cómo Las Casas, al valorar y normativizar las relaciones entre gobernantes y gobernados en estos contextos, utilizó una serie de argumentos constitucionalistas y republicanos entre los cuales destaca el origen popular del poder del gobernante, la defensa del bien común sobre los intereses particulares, la limitación de la autoridad por la voluntad del pueblo y el derecho a la libertad, entendida como no dependencia, de los hombres y las comunidades políticas.

Estos principios claramente desafían al llamado absolutismo que, hasta hace poco, como resultado de la historiografía liberal, se aceptaba como la tradición política hegemónica en el ámbito hispanoamericano durante la temprana modernidad. Por esta razón, no es raro encontrar la afirmación de que Las Casas fue "un adelantado a su tiempo", un precursor de la defensa de los derechos humanos y de la democracia contemporáneos. ${ }^{3}$ Sin embargo, lejos de ser un autor fuera de lugar, Las Casas formó parte de una tradición política arraigada en el mundo hispánico. Como veremos enseguida, el dominico fundamentó su pensamiento en las

Ibáñez y Sabatini (eds.), Polycentric Monarchies; Elliott, “Una Europa”; Garriga, “Orden jurídico”, entre otros.

3 Queraltó, El pensamiento filosófico-político; García García, “Bartolomé de Las Casas” pp. 81-114; BEuchot, Los fundamentos; entre otros. 
fuentes más convencionales de su época: el derecho común y la filosofía aristotélico tomista, y articuló sus escritos a partir del método escolástico, el cual llevaba más de tres siglos de dominar el ámbito universitario y las redes intelectuales europeas.

\section{¿CONSTITUCIONALISMO Y REPUBLICANISMO HISPANO}

EN EL SIGLO XVI?

Puede resultar polémico emplear los términos constitucionalismo y republicanismo - sobre todo el segundo- para describir el pensamiento de Bartolomé de Las Casas. Es necesario, por ello, establecer una distinción entre la forma en que empleo los conceptos en este artículo y otros usos que existen en la actualidad. Hoy en día se entiende comúnmente por constitución el código jurídico positivo que da forma a los poderes públicos y regula a una sociedad, y por constitucionalista a la entidad política que se organiza a partir de dicho código. Por otro lado, el concepto república o republicano, tras la Ilustración y la revolución francesa, se ha empleado principalmente para designar una forma de gobierno, casi siempre opuesta a la monarquía, en donde existe la división de poderes y la igualdad de los hombres ante la ley. Sin embargo, los conceptos de constitución y república en el lenguaje de la modernidad temprana tuvieron un contenido semántico distinto. Entre los contemporáneos de Las Casas, constitución era la legítima organización política de cualquier sociedad en la que la autoridad estaba limitada por una serie de normas, costumbres o principios fundamentales, anteriores e independientes del poder del gobernante. Por su parte, el concepto de república se utili- 
zaba para hablar de la comunidad de los hombres constituidos en un cuerpo político cuyo fin era el bien común, más allá de su forma de gobierno. ${ }^{4}$

Dentro de la historiografía jurídica, política y del pensamiento político, el término constitucionalismo frecuentemente se utiliza. Hay quienes lo usan desde una perspectiva "restringida", vinculada al positivismo jurisdiccional y a la idea de constitución como código jurídico arriba mencionada. Para estos autores, el constitucionalismo surgió a patir de finales del siglo XviII y se empleó a lo largo del xix, cuando se conformaron los estados nación regidos por un derecho constitucional. ${ }^{5}$ Por otro lado, es común encontrar el uso de este término en un sentido más amplio, sobre todo en estudios de historia y pensamiento políticos de periodos anteriores al surgimiento de los estados nacionales. En este sentido, el constitucionalismo se presenta como una forma de organización política o una tradición intelectual opuesta al absolutismo, en la que la legitimidad de un gobierno depende de la existencia de normas que establecen límites claros a la autoridad. ${ }^{6}$

${ }^{4}$ Cabe señalar que el uso del concepto república como forma de gobierno se utilizaba en la época dentro de algunas tradiciones, como el humanismo cívico. Sin embargo, no era su principal acepción en el mundo ibérico, ni en el ámbito universitario e intelectual ni dentro de los lenguajes administrativos de la corona, lugares en donde, es importante subrayar, el concepto se utilizaba ampliamente.

${ }^{5}$ Véase, entre otros, Alexander (ed.), Constitutionalism; Hardin, Liberalism, Constitutionalism, and Democracy. Para el ámbito hispanoamericano Aguilar, En pos de la quimera; Palacios Bañuelos y Ruiz (dirs.), Cádiz 1812; Varela, La teoría del Estado; Luna, Mijangos y Rojas (coords.), De Cádiz al siglo XXI; PIETsChmann, "El primer constitucionalismo en México"; Astudillo y Carpizo, "Presentación” pp. xi-xvi. ${ }^{6}$ Quienes han estudiado dicha tradición durante la modernidad temprana identifican entre estos límites a los usos y costumbres de los 
En décadas recientes han aparecido diversos estudios sobre esta última forma de constitucionalismo en el ámbito hispánico de los siglos xvi y xvir. Dichos trabajos se centran particularmente en el análisis de los mecanismos del ejercicio del poder dentro de la Monarquía y en los grupos que negociaron con la corona los límites de su jurisdicción en la península ibérica. ${ }^{7}$ Los estudios sobre las expresiones de esta tradición en el pensamiento hispanoamericano de la temprana modernidad son más escasos, por lo que considero necesario explorarlas con mayor profundidad, incluyendo sus manifestaciones indianas. ${ }^{8}$

pueblos; las instituciones de representación y negociación, como las cortes o los parlamentos; las leyes fundamentales de los reinos y las elaboradas por la misma autoridad; y los pactos y contratos establecidos entre el gobernante y los gobernados. Sobre esta tradición véanse TIERnEY, Religion; SKInner Los fundamentos, vol. II, pp. 119-191; Utrera, Conciliarismo y constitucionalismo; MADdox, "Constitution"; García, "Estudio preliminar"; Grossi, El orden jurídico medieval, entre otros. Para estudios sobre las diferencias o el cambio de una forma de constitucionalismo a otra, véanse Howard, Constitutionalism; La Torre, "Constitucionalismo"; GARRIGA (coord.), Historia y Constitución, en particular su capítulo "Continuidad y cambio del orden jurídico", pp. 59-106; y AnNino, "El primer constitucionalismo mexicano". Si bien este último podría incluirse en el grupo anterior, pues no habla de un constitucionalismo previo a la conformación de la nueva nación, lo que designa como "la tradición hispánica del gobierno moderado" es muy similar a la idea de constitucionalismo en un sentido amplio.

7 Además de los trabajos referidos en la nota 2, véanse Thomson, Guerra $y$ decadencia; Clavero, Tantas personas como estados; Hespanha, Visperas de Leviatán; GiL, Las claves; CenTENero, De repúblicas urbanas; ForTea, Monarquia y Cortes, entre otros.

${ }^{8}$ Entre quienes han estudiado el pensamiento constitucionalista hispano destacan Skinner, Los fundamentos, vol. II, pp. 119-191; Rubies, "La idea del gobierno mixto" y "Reason of State"; GIL, "Constitucionalismo aragonés"; Gascón Pérez, "Los fundamentos del constitucionalismo 
Por su parte, los historiadores del pensamiento político identifican al llamado republicanismo clásico o neorromano como una de las principales tradiciones intelectuales de la modernidad temprana. Esta forma de republicanismo ha sido ampliamente estudiada desde hace varias décadas, principalmente sus manifestaciones en la península itálica, Inglaterra, Países Bajos y Estados Unidos. ${ }^{9}$ En términos generales, se identifican como sus presupuestos centrales la defensa del origen popular del poder, la libertad de los ciudadanos entendida como no dependencia, el cultivo de las virtudes cívicas como una forma de afrontar la fortuna, la preeminencia del bien común sobre los intereses privados y la participación activa de los ciudadanos en su gobierno. Así mismo, como el adjetivo "clásico" lo sugiere, se reconoce que dichos principios surgieron de la reinterpretación de textos de la Antigüedad grecolatina, principalmente de Aristóteles y Cicerón, y que tuvieron una impronta fundamental del derecho romano. ${ }^{10}$ Es importante subrayar, como

aragonés"; Cañeque, The King's Living Image, y Pereña, Carta magna de los indios.

9 Entre los múltiples estudios sobre esta tradición destacan SKINnER, Los fundamentos y Liberty before Liberalism; Pocock, El momento maquiavélico; Pettit, Republicanism; VAn Gelderen y Skinner (eds.), Republicanism.

${ }^{10}$ Cabe aquí hacer un señalamiento. A partir de la década de 1970, los estudios sobre el republicanismo han tenido en Inglaterra y Estados Unidos gran auge. Este concepto funcionó para desafiar los paradigmas de la historiografía liberal, que identificaba al liberalismo como la tradición fundadora de los movimientos revolucionarios atlánticos de finales del siglo xviII. A raíz de su éxito, autores como Daniel Rodgers o Elías Palti, señalan que se han cometido abusos del concepto, al querer explicar a partir de él todos los fenómenos políticos de Occidente - y en concreto del mundo anglófono - de los siglos xviII y XIX. Si bien comparto con ellos la 
han insistido varios autores, que esta tradición, a diferencia de otras formas de republicanismo asociadas a las revoluciones de finales del siglo XVIII, no denota necesariamente una postura antimonárquica, pues si bien entre muchos autores considerados republicanos se presentó una crítica a la monarquía, no es la oposición a esta forma de gobierno lo que lo define. ${ }^{11}$

La presencia de los principios republicanos mencionados entre autores del Renacimiento italiano y su desarrollo posterior en naciones del Atlántico Norte son comúnmente aceptados por la historiografía del pensamiento político. ${ }^{12}$ No obstante, sus manifestaciones en el mundo hispanoamericano de la modernidad temprana - caracterizado por

preocupación por esta situación, me parece que el republicanismo como concepto historiográfico sigue teniendo un gran valor heurístico, siempre y cuando se haga explícita la manera en que se está utilizando. En este artículo busco mostrar esto último, cuando menos para el mundo hispánico de la temprana modernidad. Para una crítica a la historiografía del republicanismo véanse Rodgers, "Republicanism: the Carrer of a Concept", y PALti, "Las polémicas en el liberalismo argentino".

${ }^{11}$ Así, por ejemplo, Skinner y Van Gelderen destacan el antimonarquismo de muchos autores del republicanismo clásico, pero advierten que: "paradoxically, however, the upholding of civic liberty was not invariably taken to require a republican constitution in the strictest sense. Sometimes it was conceded that, if one could have a Doge-like monarch, subject to election and bereft of prerogative powers, this might offer the best prospect of assuring the right combination of public order and civil liberty. This paradox echoes throughout the early modern period. We encounter it in Machiavelli's question as to whether a republica can be sustained 'per via di regno', and we hear it again in Hume's suggestion that the progress of the arts and the maintenance of liberty may often fare better under 'civilised monarchies", VAN Gelderen y Skinner, "Introduction", p. 3. ${ }^{12}$ Esta es una de las tesis centrales de la obra clásica de Pocock, El momento maquiavélico. 
la historiografía generalmente como absolutista - resulta, cuando menos, controversial. Entre los historiadores que han estudiado el republicanismo clásico durante dicho periodo hay quienes no atienden el ámbito hispánico ${ }^{13} \mathrm{y}$ quienes explícitamente cuestionan su presencia dentro de estas latitudes. ${ }^{14}$ Una explicación de esto es la asociación que se tiende a establecer entre republicanismo clásico y humanismo cívico. Ciertamente, en el siglo xvi fueron los humanistas del Renacimiento los principales defensores de las ideas republicanas y también es cierto que el humanismo cívico tuvo una presencia limitada - aunque no nulaen el mundo hispánico. No obstante, como mostraré con el ejemplo de Las Casas, no fue el humanismo cívico el único lenguaje que usó postulados que podrían identificarse como republicanos.

Quienes han estudiado con mayor profundidad formas de republicanismo en Hispanoamérica son los historiadores de las independencias y del periodo de construcción de los estados nacionales. Entre ellos, existe también la tendencia a cuestionar la existencia de tradiciones republicanas

${ }^{13}$ Entre ellos se podría nombrar a Philip Pettit, Quentin Skinner o Martin van Gelderen.

${ }^{14}$ Probablemente el más destacado es John Pocock. En el prólogo a la edición española de The Machiavellian Moment, Pocock cuestiona seriamente, sin dar mayores argumentos, la existencia de un republicanismo clásico español. Señala Pocock refiriéndose a sí mismo: "El autor -con acierto o sin él- ha encontrado pocos rastros del republicanismo clásico en el pensamiento español moderno, y cree que en España la república ha sido un fenómeno privativo de los siglos xIx y xx", Рососк, El momento maquiavélico, p. 75. Otros autores que abiertamente cuestionan la existencia de un republicanismo hispánico en los siglos XVI y XVII son VILLACAÑAS, "Republicanismo clásico en España”, y Ruiz, "El republicanismo clásico en el pensamiento hispano", entre otros. 
hispánicas anteriores al siglo XIX o, cuando más, conceden su presencia a partir de la segunda mitad del siglo XviII. ${ }^{15}$ Esto se debe a que en dichos estudios el concepto republicano está estrechamente vinculado al antimonarquismo o bien, a su oposición a ciertos postulados del liberalismo. Es claro que si el concepto se asocia a la defensa de una forma de gobierno opuesta a la monarquía resultará difícil admitir la existencia de principios republicanos entre pensadores que, como Las Casas, no sólo no desafiaban al régimen monárquico sino que reconocían su conveniencia. ${ }^{16}$ Asimismo, si se define al republicanismo por su oposición al liberalismo, ¿cómo reconocer su presencia en momentos o lugares donde no existía tal tradición? Utilizar el concepto republicano para referir una teoría sobre la forma de gobierno o como una tradición de corte antiliberal me parece correcto, en tanto se haga explícita la manera en que se entiende. Sin embargo, esto no debería ser obstáculo para aceptar la existencia de otras formas de republicanismo en lenguajes políticos previos que sostuvieron, en el mundo hispanoamericano, principios como el origen popular del poder del gobernante,

${ }_{15}$ Véanse, por ejemplo, Aguilar y Rojas (coord.) El republicanismo en Hispanoamérica; en particular Aguilar, "Dos conceptos de república"; Rojas, "La frustración del primer republicanismo", y Ávila, "Pensamiento republicano hasta 1823”. También RoJas, Las repúblicas de aire; Chust y Frasquet, “Orígenes”, entre otros.

${ }^{16}$ Casi todos los autores que analizan el republicanismo latinoamericano del XIX apuntan que el concepto no debe restringirse a designar una tradición antimonárquica y reconocen - recuperandola de la historiografía anglófona - la idea de un republicanismo en un sentido amplio. Pero también, prácticamente todos ellos, ubican la existencia de principios republicanos en América Latina únicamente cuando se presenta en su forma antimonárquica, como si el concepto se restringiera en estas latitudes a una forma de gobierno. 
el bien común como el fin de la sociedad, la ley y la voluntad de la comunidad como límite a la autoridad, la búsqueda de la participación de la república en el gobierno y la defensa de la libertad de los pueblos y ciudadanos. ${ }^{17}$

Finalmente, en los últimos años han aparecido trabajos que reconocen la presencia de autores o prácticas republicanas en el mundo hispánico de la temprana modernidad. Éstos se han centrado en el análisis de manifestaciones aisladas del humanismo cívico en la península ibérica, en las reacciones de las ciudades aragonesas y castellanas ante la presión centralizadora de la corona y, en menor grado, en algunos autores escolásticos. ${ }^{18} \mathrm{El}$ presente artículo sigue

17 Más aún, cuando al describir las tradiciones del siglo xIx se está recuperando el concepto de republicanismo clásico de quienes lo han estudiado en la modernidad temprana, como Pocock o Skinner. Véase, por ejemplo, RoJas, "La frustración del primer republicanismo mexicano" o AgUILAR "Dos conceptos de república". Este último, refiriéndose a la Monarquía española de la modernidad temprana, señala que "a pesar de que el impacto humanista del aristotelismo se sintió en España más o menos al mismo tiempo que en Italia, para fines del siglo xvi España se hallaba al borde 'de ese desesperante oscurantismo tan característico de los siglos XVI y xvir' [cita de Anthony Pagden]. Cuando el pensamiento político florentino prosperaba en Italia, la Escuela de Salamanca se encontraba, por el contrario, volcada en la neoescolástica y el pensamiento especulativo", pp. 62-63. Considero, al igual que Erika Pani, que reconocer una cultura republicana en Hispanoamérica de más largo alcance puede resultar muy útil para analizar el republicanismo antimonárquico y antiliberal del siglo XIX; véase PANI, "Maquiavelo en el septentrión”, p. 297.

18 Véanse, entre otros, GiL, "Ciudadanía” y "Republican Politics"; Rubies, "La idea del gobierno mixto"; Centenero, De repúblicas urbanas; Marcano, "Del republicanismo clásico", y Velasco, Republicanismo y multiculturalismo, pp. 35-106. Velasco, cabe destacar, ha sido el gran impulsor - desde la filosofía política, no desde la historiografía - de la idea de un republicanismo novohispano y ubica entre sus más importantes representantes a Bartolomé de Las Casas. 
esta línea de investigación. Al centrarme en la figura de Bartolomé de Las Casas busco mostrar cómo, lejos de presentarse como marginales, los argumentos republicanos y constitucionalistas ocuparon un lugar central en los debates políticos de la época, cuya proyección no se limitó a la península ibérica, sino que incluyó, en particular, a las Indias Occidentales.

Para concluir este apartado quisiera advertir que mi objetivo no es mostrar hasta qué punto en Bartolomé de Las Casas o en el mundo hispánico del siglo xvi podemos encontrar un verdadero republicanismo o un verdadero constitucionalismo. El hacerlo supondría que existe una forma ideal de estas tradiciones y que mi labor consistiría en buscar cómo se realizó en un autor o en un momento determinado, es decir, caer en lo que Elías Palti ha denominado "el presupuesto del modelo y la desviación". ${ }^{19}$ Lo que busco, en cambio, es mostrar cómo muchos de los conceptos y presupuestos políticos que designan estas categorías historiográficas, cómo una serie de argumentos que los historiadores identifican como característicos de dichas tradiciones, estuvieron disponibles en el ámbito hispanoamericano de la modernidad temprana y fueron utilizados de forma específica por Bartolomé de Las Casas para debatir problemas políticos de su época.

19 Palti, La invención de una legitimidad, pp. 23-44. Una crítica similar a esta forma de proceder de la historia del pensamiento político en SKINNER, “Significado y comprensión”, pp. 66-76. 
EL MÉTODO Y LAS FUENTES DE BARTOLOMÉ DE LAS CASAS

Las Casas redactó a lo largo de su vida gran número de cartas, memoriales, historias y tratados. ${ }^{20}$ En el presente artículo analizo sus tres últimas obras - las menos trabajadas por la historiografía-, De thesauris, Doce dudas y De regia potestate, pues es en ellas donde el dominico desarrolló de manera más contundente los argumentos que identifico como constitucionalistas y republicanos. Las dos primeras él mismo las consideró como su legado espiritual al $D e$ thesauris lo denominó su testamento y a las Doce dudas su codicilo. Ambos textos fueron escritos para ser leídos ante el Consejo de Indias y tienen como punto de partida polémicas vinculadas al virreinato del Perú. ${ }^{21}$ En ellos, Las Casas establece su crítica más radical al dominio español sobre las Indias y presenta su propuesta más puntual sobre los requisitos para que la corona española pudiera ejercer un legítimo gobierno sobre las Indias sin afectar la libertad de los pueblos americanos. Por su parte, De regia potestate, como su

${ }^{20}$ Para una relación de sus escritos, véase VALdivia, Llamado a la misión pacífica, pp. 55-64.

${ }^{21}$ De thesauris o Los tesoros del Perú, redactado alrededor de 1563, parte del problema del saqueo de las tumbas de los gobernantes incas que llevaron a cabo los conquistadores y lo usa como punto de partida para discutir la legitimidad del dominio español sobre América. El texto se mantuvo inédito hasta 1958, aunque se conocen varias copias manuscritas. Por su parte, las Doce dudas las escribió Las Casas hacia 1564, como respuesta a un Memorial de agravios redactado por el también dominico Bartolomé de Vega. En el tratado se presenta - como el título de la obra lo indica - una respuesta a 12 dudas sobre temas relacionados con la dominación española sobre América, como la encomienda, los tributos, la minería o la legitimidad de los señoríos indígenas. El tratado se imprimió por primera vez en 1992. 
nombre refiere, es un análisis sobre la potestad real, el cual parte de la duda sobre si los reyes tienen derecho a enajenar a sus súbditos. Al dar respuesta a tal problema, el dominico presenta las condiciones necesarias para ejercer el poder dentro de un reino sin afectar la libertad de los ciudadanos. En este sentido, puede ser considerado como un tratado sobre los límites de la autoridad. Ahora bien, a diferencia del resto de sus obras que discuten analizan el problema indiano, De regia potestate no se centra en el análisis de la relación entre naciones sino en las tensiones de los sujetos políticos que constituyen los reinos, en las relaciones del rey con los ciudadanos, con las ciudades y otras corporaciones. $^{22}$

Estas obras, al igual que la mayoría de sus tratados, están formuladas en términos del lenguaje escolástico. Recordemos que la escolástica fue el modelo de conocimiento que dominó el mundo universitario europeo durante la edad media y la modernidad temprana. Asimismo, cabe mencionar que, durante la vida de Las Casas, en los reinos ibéricos tuvo lugar un movimiento de renovación de la teología

22 El libro fue publicado en Frankfurt de manera póstuma en 1571 y existen dudas sobre la autoría de Las Casas. Más allá de la posibilidad de que el tratado fuera apócrifamente publicado bajo el nombre del dominico me parece que, por las ideas contenidas en él, puede aceptarse como de su pluma si no se demuestra lo contrario. Si bien es cierto que resulta extraño que no existan referencias directas al Nuevo Mundo, los principios políticos mediante los cuales Las Casas establece la defensa de los indios en tratados como De thesauris, Doce dudas o Principia quaedam son los mismos que los que se desarrollan de manera teórica y normativa en la obra De regia potestate. Incluso, Principia quaedam y De regia potestate comparten un pasaje idéntico al tratar sobre un tema medular en el pensamiento lascasiano, el asunto de la libertad. Véanse Casas, De regia potestate, pp. 34 y 36; CASAs, "Principia quaedam”, pp. 1248 y 1250. 
escolástica conocido por la historiografía como Escuela de Salamanca o segunda escolástica. ${ }^{23}$ Una de las características de este movimiento fue la revaloración de los principales autores clásicos y medievales para el análisis de problemas morales, jurídicos y políticos concretos de su tiempo. Las Casas puede considerarse parte de esta corriente aunque, como se verá más adelante, en algunos puntos se distanciará de la postura general de los teólogos de la llamada segunda escolástica.

Al igual que los teólogos y juristas escolásticos, los escritos de Las Casas parten de cuestiones o dudas particulares que buscan resolver con razonamientos deductivos y evidencias históricas y, sobre todo, a partir de la cita e interpretación de textos considerados autoridades. ${ }^{24}$ En el método escolástico, las fuentes canónicas brindan al autor opiniones probables y cercanas a la certeza que, mediante su glosa, permiten analizar y brindar una solución al problema en cuestión. Estas autoridades, en el caso de los tratados que nos ocupan, están constituidas por un cuerpo compacto de fuentes que responden principalmente a dos tradiciones: la filosofía aristotélico tomista y el derecho común.

Aristóteles y Tomás de Aquino fueron autores ampliamente utilizados en la teología bajomedieval y de la modernidad temprana. Las obras del primero brindaron categorías fundamentales al pensamiento occidental, como las de

${ }^{23}$ Sobre este tema véase Pena González, La Escuela de Salamanca; Belda, La Escuela de Salamanca; Brett, Liberty, Right and Nature, entre otros.

${ }^{24}$ Cárdenas Bunsen analiza con detenimiento el método empleado por Las Casas, al cual identifica con la glosa jurídica; véase CÁrdenas, Escritura y derecho canónico, pp. 71-171. 
esencia, accidente, causa o fin. Dentro de la teología o filosofía moral, la Política y la Ética fueron los textos aristotélicos más citados por los autores escolásticos y Las Casas, en este sentido, no es una excepción. Por su parte, las sumas y tratados de Tomás de Aquino, escritos en términos aristotélicos, ofrecían un arsenal sistematizado de respuestas a problemas teológicos relacionados con Dios, el hombre y la naturaleza, dentro de los cuales eran atendidas también cuestiones morales y políticas. ${ }^{25}$

El derecho común, por otro lado, está constituido por dos grandes cuerpos jurídicos: el derecho romano y el canónico, así como por las glosas y comentarios elaborados en torno a ellos por juristas y canonistas. De los textos del derecho romano conocidos como Corpus Iuris Civilis, fueron las Instituta, el Codex y el Digestum los libros más utilizados por Las Casas y, en general, por los autores escolásticos. ${ }^{26}$ Dichos libros están compuestos por leyes de la época imperial y por una serie de máximas o sentencias de juristas romanos en torno a un gran número de temas, entre los que se incluyen la justicia, la esclavitud, la propiedad, la jurisdicción y la ley. ${ }^{27} \mathrm{El}$ otro cuerpo jurídico que compone

${ }^{25} \mathrm{Al}$ discutir problemas políticos son principalmente utilizadas las partes de la Suma teológica donde se analizaba el problema del origen del hombre y su dominio sobre las cosas (1a, pp. 93-96), el problema de las leyes (1a-2ae, pp. 90-106), y la de la justicia y el derecho (2a-2ae, pp. 57-120).

${ }^{26}$ Esta recopilación fue realizada por orden de Justiniano I entre 529 y 534. Los otros libros que componen el cuerpo del derecho romano son el Codex repetitae praelectonis y las Novellae constitutiones.

${ }^{27}$ Así, por ejemplo, el primer título de las Instituciones establece que "Justicia es la constante y firme voluntad que da a cada uno su propio derecho" y la ley 2 del título VIII del Digesto recoge la máxima de Marciano que señala "Algunas cosas son comunes a todos por derecho natural, 
el derecho común es el Corpus Iuris Canonici. Este es, igualmente, una colección de normas jurídicas, elaboradas en este caso para el gobierno de la Iglesia. ${ }^{28}$ Aunque estos textos se utilizaban sobre todo para discutir problemas relativos a la jurisdicción eclesiástica, incluyendo entre ellos el tema del pecado, en muchas ocasiones - como veremos en el caso de Las Casas - las normas canónicas se recuperaban para analizar problemas del gobierno secular. ${ }^{29}$

Cabe señalar que los cuerpos jurídicos que componen el derecho común no presentan una teoría política sistemática y coherente. El conjunto de normas y máximas que los constituyen apuntan hacia una gran diversidad de problemas y posturas políticas, muchas veces contradictorias. Así, por ejemplo, algunos principios contenidos en ellos defienden el poder irrestricto del gobernante, mientras que otros

otras son de la comunidad, otras no pertenecen a nadie y la mayor parte son de particulares, las cuales se adquieren para cada cual por diversas causas"; sigo la edición de García DEL CoRRAL, Cuerpo del derecho civil romano, t. I. pp. 5 y 225.

${ }^{28}$ Las leyes de este cuerpo legal para la época de Las Casas fueron recopiladas en distintos libros entre 1140 y 1503. Los textos más usados por Las Casas son el Decretum de Graciano y las Decretales de Gregorio IX. Además de estas obras, el Corpus Iuris Canonici, para mediados del siglo xvi, contenía el Liber Sextus, las Clementinae, las Extravagantes y las Extravagantes communes.

${ }^{29}$ Esto era resultado de la estrecha relación que prevaleció en el orden jurídico del antiguo régimen entre el gobierno temporal y el espiritual. Esta relación es muy clara en Las Casas, quien, por ejemplo, al analizar las acciones llevadas a cabo por la corona española en Indias atendía a su validez jurídica, pero también a su relación con el foro de la conciencia, es decir si se cometía o no pecado. De esta forma, como señala Cárdenas, los remedios propuestos por Las Casas se suelen mover del plano del bienestar temporal al del cuidado de las conciencias; véase CáRDENAS, Escritura y derecho canónico, pp. 38-47. 
la necesidad de atender a la voluntad de la comunidad para los asuntos de gobierno. Por esta razón, tanto el derecho romano como el canónico se usaron indistintamente por personajes que asumieron posturas absolutistas, constitucionalistas o republicanas.

$\mathrm{Al}$ analizar las fuentes referidas por Las Casas en sus tratados de las décadas de 1550 y 1560 , es evidente que las referencias a los cuerpos del derecho civil y canónico y a sus comentaristas son más numerosas que las hechas a teólogos o a textos aristotélicos. ${ }^{30}$ Como veremos más adelante, al tratar temas políticos, los principios contenidos en ambos derechos - principalmente el romano - funcionan como ladrillos con los que Las Casas va construyendo sus argumentos. ${ }^{31}$ No obstante, las categorías aristotélicas y tomistas no dejan de ser fundamentales en los escritos lascasianos, en tanto que son las que brindan estructura a su pensamiento.

Las Casas, pues, edificó su pensamiento con material proveniente de las tradiciones aristotélica y del derecho romano

30 No así en sus historias escritas en momentos anteriores. Quizá, por ello, el lugar que ocupan estas fuentes en el pensamiento de Las Casas ha sido un tema discutido por la historiografía. A principios de los años noventa, Kenneth Pennington señalaba que existían entre los historiadores dos grandes posturas para explicar el pensamiento lascasiano: una que era esencialmente tomista y otra que era ecléctica e incoherente. Ante esta dicotomía, el estadounidense propuso una tercera explicación que era esencialmente jurista; véase Pennington, "Bartholome de Las Casas". Esta lectura ha sido recuperada por otros investigadores, los cuales han mostrado la importancia del derecho común, particularmente el canónico, en la argumentación de Las Casas; véanse CÁRDENAS, Escritura y derecho canónico, y NaIr, "Contra imperio", entre otros.

${ }^{31} \mathrm{Al}$ tratar temas relativos al poder secular, las fuentes del derecho romano ocupan un lugar más importante que las del canónico, razón por la cual difiero de la tesis central de Cárdenas, quien sostiene lo contrario. 
y canónico. Si le sumamos a ello que conoció y utilizó textos de pensadores latinos como Cicerón y Salustio, encontramos que el dominico, al igual que otros escolásticos, trabajó con las mismas fuentes utilizadas durante la época por autores de tradiciones como el humanismo cívico italiano y del norte de Europa. ${ }^{32}$ Esta base común de textos hizo posible que Las Casas compartiera con los pensadores vinculados a tales tradiciones presupuestos políticos similares, aunque la diferencia en el contexto polémico y lingüístico en donde los utilizaron dotaría a cada uno de sus propias características.

EL ORIGEN DEL PODER POLÍTICO O JURISDICCIÓN

Quienes están familiarizados con el pensamiento político medieval y de la modernidad temprana saben que durante estos periodos existieron diversas explicaciones del origen del poder y que, a diferencia de lo que plantea la historiografía de corte liberal, éstas no se redujeron a concepciones teocráticas. La amplia gama de posturas podría ser ordena$\mathrm{da}$ en tres grupos distintos: por un lado, quienes defendían el origen divino del poder y su trasmisión a los gobernantes directamente de Dios, a través del papa o de la comunidad; por otro, quienes lo explicaban como el resultado de la imposición - ya fuera por fuerza o por virtud - de unos hombres sobre otros; $y$, finalmente, quienes sostenían que dicho poder existía por naturaleza y era trasmitido a los gobernantes por la comunidad en su conjunto. Las Casas

32 Sobre este tema véase SKInner, "The rediscovery of republican values"; Kelly, "Civil science in the Renaissance”, y Pocock, Elmomento maquiavélico. 
se adscribiría al último grupo al defender el carácter natural y comunitario del poder político y en su postura ante este problema se puede apreciar la integración que hace de las tradiciones aristotélicas y del derecho común.

Para Las Casas el poder político estaba fundamentado tanto en el derecho natural como en la voluntad de los hombres. Siguiendo los planteamientos de Aristóteles, sostenía que el poder político o jurisdicción era de derecho natural en tanto que no era una creación humana y existía como tal por naturaleza. ${ }^{33} \mathrm{Al}$ considerarlo de derecho natural, Las Casas asumía que el poder político era necesario para que el hombre pudiera realizarse, para que alcanzara el fin de su existencia terrena: vivir bien. Para el dominico, como lo argumentaba Aristóteles, el hombre era un animal social que requería la comunidad para sobrevivir; y la comunidad, a su vez, necesitaba de alguien que la rigiera y gobernara políticamente. Así explicaba Las Casas el carácter natural de la sociedad política:

Cuando alguna cosa es a otra natural, todo aquello le es también natural de necesidad, sin lo cual aquella no se puede haber o alcançar, porque la naturaleza no faltara en las cosas necesarias, según el Filósofo [Aristóteles] enseña en el 3 De anima. Pues, así es que vivir los hombres en compañía de otros, vida políti-

${ }^{33}$ Siguiendo la lectura que Tomás de Aquino hizo de Aristóteles, sostenía que el derecho natural era una serie de preceptos universales y sus conclusiones inmediatas, obtenidos por medio de la razón natural, mediante los cuales los hombres debían ordenar su vida moral. El principio más básico del derecho natural era buscar el bien y evitar el mal con el fin de la conservación de la vida y de este precepto se desprendían todos los demás; véanse, CASAs, Doce dudas, p. 112, y CASAS, Apologética, vol. I, pp. 212-213. 
ca y social, como en lugares y ciudades, es a los hombres natural según el mismo Filósofo, 1 Politicorum, y la razón da, conviene a saber: porque vivir un hombre solo, o una casa de marido y mujer y hijos sola, no podría sustentarse ni vivir mucho tiempo por las muchas necesidades que ocurre, las cuales no puede uno ni pocos remediar y suplir. Luego, todo aquello que para sustentar aquella compañía o sociedad fuere necesario, serle ha natural y debérsele ha de Derecho natural. Y esto es, y principal entre otras cosas, tener quien rija y gobierne aquella compañía y comunidad y tenga cargo del bien común. Porque siendo muchos ayuntados sin quien los rija, engendraríase confusión como es claro, y por consiguiente la comunidad se desharía y no se conservaría, contra lo que la naturaleza pretende, dando a los hombres de vivir en compañía inclinación natural. ${ }^{34}$

Si bien Las Casas reconocía el carácter natural del poder político, la forma en que se ejercía y el hecho de que una persona y no otra lo detentara, no resultaba de la naturaleza sino de la voluntad de los hombres y del derecho de gentes. ${ }^{35}$ Inmediatamente después de la cita anterior aparece en el tratado la siguiente aclaración: "Este regente o gobernador no es ni puede ser otro, sino aquel que toda la comunidad eligió al principio, o donde no lo tuviere elegido eligiere”. ${ }^{36}$

${ }^{34}$ Las Casas, Doce dudas, p. 36.

${ }^{35}$ En este sentido Las Casas menciona que la jurisdicción estaba perfeccionada y confirmada por el derecho de gentes. Las Casas, siguiendo a los juristas escolásticos, concebía al derecho de gentes como los acuerdos o pactos comunes, desprendidos de la razón natural, que la comunidad de los hombres había establecido. Casas, "Principia quaedam", p. 1239. Sobre las distintas interpretaciones del derecho de gentes para esa época, incluyendo la de los juristas, véase BRETT, Changes of State, pp. 77-78. 36 CASAs, Doce dudas, p. 37; Las Casas cita tras esta afirmación cuatro pasajes del Digesto, y los comentarios de juristas y canonistas a un pasaje 
Así, aunque el poder político existiera por naturaleza, no era por esta causa que los gobernantes lo ejercían justamente, sino solo porque el pueblo decidía libremente otorgarles la jurisdicción que le era propia para que promovieran el bien de la comunidad. Este movimiento no convertía al gobernante en el poseedor de la jurisdicción, sino solo en su administrador, como claramente lo estipulaba el dominico:

La jurisdicción es en cierto modo una cosa ajena al rey porque no recibe la jurisdicción como dueño de la misma y el pueblo no se la dio para que abusase de ella, sino para que usase de ella por sí y por sus jueces y magistrados, hombres buenos, para proteger al pueblo. ${ }^{37}$

Al ser la comunidad o el pueblo en su conjunto quien delegaba la jurisdicción al gobernante, el único fin de esa delegación, de la institución misma del poder político, era el bien común y por ello no podían nunca anteponerse los intereses individuales - menos aún los del gobernante- al bienestar de la república. Así lo establecía Las Casas utilizando las categorías aristotélicas al señalar que "el pueblo

del Digesto y uno de las Decretales respectivamente. La misma idea aparece en De thesauris: "desde el principio, todo principado o régimen político sobre un pueblo tiene su origen en el consentimiento y elección de dicho pueblo", refiriendo como autoridad al respecto leyes del Digesto, las Instituta, las Nouellae Constitutiones y la introducción al Codex, p. 215.

37 Casas, De regia potestate, p. 111. Como se aprecia en esta cita, Las Casas utiliza frecuentemente el concepto pueblo (populus en latín) para referirse al conjunto de los hombres constituidos como cuerpo político, intercambiándolo con otros conceptos como el de comunidad o república. 
fue la causa eficiente y final de los reyes y príncipes, por lo que éstos están ordenados al pueblo, o al bien del pueblo, y a la utilidad común como a su fin". ${ }^{38}$ Entre las obligaciones del gobernante hacia el bien común se encontraban promover y garantizar la paz, la multiplicación y sucesión de la población, la virtud de los ciudadanos y la defensa ante enemigos internos y extranjeros. ${ }^{39}$

Es importante destacar que, a diferencia de la mayor parte de los teólogos escolásticos de la primera mitad del siglo xvI, Las Casas prefería utilizar el término jurisdicción sobre el de dominio para referirse al poder político. Esto supone un distanciamiento entre el lenguaje político empleado por Las Casas y aquel de ciertos teólogos de la llamada Escuela de Salamanca. El término jurisdicción no era desconocido ni ajeno a autores como Francisco de Vitoria, Domingo de Soto o Alonso de la Veracruz; no obstante, éstos preferían usar el concepto teológico dominio de la teología medieval. ${ }^{40}$ Las Casas, en cambio, optaba por utilizar el término iurisdictio, preferido en la tradición romana, sobre todo en sus últimos tratados. ${ }^{41} \mathrm{El}$ hecho de que exista en Las Casas este desplazamiento nos habla, por un lado, de la fuerte

38 CAsas, De regia potestate, p. 81 . La misma idea, aunque citando el Decreto de Graciano, aparece en la p. 63.

39 Casas, Doce dudas, p. 93; Casas, De regia potestate, p. 83.

40 Sobre el uso del concepto dominium ente los escolásticos véanse Brett, Liberty, Right and Nature; Burns, Lordship; Hespanha, Cultura jurídica europea, pp. 95-96.

41 Todavía en "Principia quaedam” de 1551, Las Casas hace un uso indistinto de los términos dominio y jurisdicción. Sin embargo, en sus últimos tratados, sobre todo en el De regia potestate, los distingue claramente, llegando a señalar que impropiamente se utiliza el concepto dominio para referirse a la jurisdicción; CAsAs, De regia potestate, p. 67. 
incidencia que tiene el derecho romano en su pensamiento, que se fue haciendo más importante conforme alcanzaba su madurez intelectual, pero también del interés del dominico por marcar de manera explícita la diferencia entre la idea de dominio como propiedad y la de jurisdicción como poder político, y los distintos alcances, derechos y obligaciones que de cada una se derivaban, evitando con ello posibles confusiones.

El dominio como derecho de propiedad, el uso apropiado del término según Las Casas, era el poder del dueño para usar a su antojo y discreción los bienes que legítimamente poseía. ${ }^{42}$ Por su parte, la jurisdicción era concebida por Las Casas como "la sustancia y el fundamento de todo cuanto el rey, rector o cualquier juez hace en toda la república”. ${ }^{43}$ Se trataba de un poder que se ejercía en el ámbito público, que otorgaba la facultad de imponer coactivamente las decisiones y cuyo fin era resguardar el orden y garantizar la reproducción y el bienestar de la comunidad. La jurisdicción remitía en primer lugar a la administración de justicia, al dictar y establecer el derecho. No obstante, el concepto era utilizado por Las Casas de una forma más amplia, no solo para designar la actividad judicial sino también a facultades gubernativas. Como lo señala Pedro Cardim, la juris-

${ }^{42}$ El dominico señalaba que este existía en el derecho natural solo como el derecho que Dios había dado a los hombres de poseer en común todas las cosas de la Tierra. La propiedad privada era, entonces, una institución humana basada en el derecho de gentes, pues éstos, con la concesión divina, habían introducido y aprobado que las tierras y las cosas se dividieran y repartieran; CASAS, De regia potestate, p. 43, y CASAS, "Principia quaedam", 1237.

${ }^{43}$ Casas, De thesauris, p. 371. 
dicción era concebida por los juristas escolásticos como la legítima potestad cuyas funciones abarcaban elementos judiciales, normativos y administrativos. ${ }^{44}$ Esta era la forma en que Las Casas utilizaba el concepto.

La insistencia de Las Casas en distinguir entre dominio y jurisdicción al hablar del poder político cobraba especial relevancia en tanto que, para él, el rey y todos los gobernantes no eran dueños, amos o señores (domini) de sus reinos ni de sus súbditos, sino solamente, en cuanto depositarios de la jurisdicción, "rectores, prepósitos y administradores de las repúblicas". ${ }^{45}$ La diferencia entre dominio y jurisdicción tenía, evidentemente, implicaciones fundamentales con respecto a los límites del ejercicio del poder.

\section{LOS LÍMITES DE LA AUTORIDAD}

Para Bartolomé de Las Casas el poder político debía ser restringido, pues de lo contrario se tornaría en tiranía. Dónde y cómo se establecían los límites a la autoridad son cuestiones centrales de sus últimos tratados y también se encuentran vinculados al problema de cómo mantener la libertad bajo el poder político.

De la misma forma en que el origen y la legitimidad de la jurisdicción estaban fundamentados en el derecho natural y en la voluntad de la comunidad, para el autor, los límites que los gobernantes tenían a la hora de ejercerlo estaban

\footnotetext{
${ }^{44}$ Cardim, "La jurisdicción real", pp. 356-357.

45 Casas, De regia potestate, pp. 67-69; CASAs, Doce dudas, p. 209. Las Casas refiere al hablar de esto a la autoridad de Aristóteles, Séneca y Tomás de Aquino, así como a juristas y canonistas, en particular los comentarios de Bartolo al Digesto.
} 
definidos por estos elementos. En cuanto al primero de ellos, partiendo del pensamiento iusnaturalista de Tomás de Aquino, Las Casas señalaba que todos los príncipes y reyes debían gobernar de acuerdo a los principios del derecho natural, los cuales eran accesibles a los hombres mediante la razón. ${ }^{46}$ Estos principios obligaban a las autoridades moral y jurídicamente, y establecían los límites para administrar la república, dictar justicia y legislar. ${ }^{47} \mathrm{El}$ derecho natural era, pues, el primer regulador de la actividad política y a ningún gobernante le estaba permitido hacer nada contra él. ${ }^{48}$ Así, por ejemplo, el perjurio, el robo y la estafa estaban prohibidos por derecho natural, por ello, ningún gobernante podía cometerlos, más allá de que estuviera o no estipulado en el derecho positivo. ${ }^{49}$ Asimismo, si el rey o un magistrado ordenaban algo en contra del derecho natural y la utilidad común, tanto los gobernantes subalternos como quienes recibían el mandato podían rechazarlo legítimamente, incluso con la fuerza. ${ }^{50}$

El otro límite fundamental de la autoridad era la voluntad libre del pueblo y el establecimiento de pactos entre gobernantes y gobernados. Al ser la comunidad quien decidía sujetarse voluntariamente a la autoridad de uno o varios

${ }^{46}$ Casas, De regia potestate, pp. 85-87; CASAs, De thesauris, pp. 88-93.

47 Casas, De thesauris, p. 127. Al sostener esta idea, Las Casas cita varios pasajes de los cuerpos del derecho canónico y civil, con sus respectivos comentaristas.

${ }^{48}$ Casas, De regia potestate, p. 111. Casas, De thesauris, pp. 73 y 81.

${ }^{49}$ Casas, De regia potestate, p. 87.

50 CAsas, De thesauris, pp. 259-261, en donde remite a las leyes de Castilla, las Novellae y el Codex, en particular el principio "si contra ius et publicam utilitatem". 
gobernantes, ésta poseía la facultad de establecer las condiciones del gobierno:

Porque la razón natural dicta y enseña que cualquiera pueblo o gente libre que se determinase de sujetar al gobierno, jurisdicción y principado de alguno o algunos, y de libre hacerse sujeto obligando sus personas a la dicha fidelidad que según los juristas es una especie de servidumbre, y a cumplir los otros derechos y cargas que a la tal sujeción se siguen, que pueden pedir e asentar las condiciones que quisiere, con que no sean contra la razón natural, mayormente si fueren favorables al bien público. ${ }^{51}$

El fundamento y las condiciones sobre las cuales se establecían las condiciones de gobierno entre los pueblos y sus gobernantes son desarrollados en De thesauris. En ellos se manifiesta el carácter profundamente contractual de su postura:

De aquí que haya sido costumbre establecida entre todos los pueblos y gentes, al hacer la designación y elección de sus reyes, desde el primer momento en que se propusieron crear y designar sobre sí magistrados o reyes, o en la coronación de éstos o en el momento en que son aceptados sus sucesores, hacer algún tratado, pacto, ley, convención o acuerdo, o renovar los ya hechos con los predecesores, entre ambos, esto es, entre el rey y el pueblo; y esto espontáneamente y de buena fe. En tal tratado o pacto se estipulará la manera de ejercer la potestad y jurisdicción regias: el rey prometerá de palabra, bajo juramento, y por escrito, jurando tácita o expresamente que velará debidamente por el pueblo, que introducirá un buen régimen, que concederá libertades y exenciones, que favorecerá las buenas costumbres

${ }^{51}$ Casas, Doce dudas, p. 79. La misma idea en CaSas, De thesauris, pp. 305-306. 
que se mantienen por tradición desde la antigüedad, o, si éstas no existen, o al pueblo ya no le agradan las viejas costumbres, que favorecerá otras nuevas y otros privilegios favorables que el pueblo pida para sí, para su conservación, en el marco de un perfecto estado de toda la república. [...] Nos encontramos aquí con un contrato recíproco que brota de una y otra parte; con una obligación que surge de la voluntad de las partes. Por ello decimos que, al hacerse un pacto, aunamos voluntades diversas. Así, el rey, rector o magistrado queda, en consecuencia, obligado al reino o a la república y, a su vez, el reino y la república quedarían obligados al rey o al magistrado. ${ }^{52}$

El derecho de la comunidad de intervenir en el gobierno de la república no se limitaba al establecimiento de leyes fundamentales o pactos a la hora de designar a la autoridad - en la constitución en el sentido aristotélico - sino que lo mantenía en todo momento. Recordemos que este autor consideraba que la jurisdicción no era una posesión del gobernante sino de la comunidad. Esto implicaba que los primeros necesitaran el consentimiento del pueblo para llevar a cabo las acciones de gobierno. Las Casas resume su argumento retomando la máxima jurídica Quod omnes tangit debet ab omnibus approbari, es decir, lo que concierne a todos debe ser aprobado por todos..$^{53}$

52 CASAs, De thesauris, pp. 307-309. En párrafos que siguen a esta cita, donde continúa desarrollando la idea, hace diversas referencias a pasajes del Digesto, Codex, Decretales y del Decretum de Graciano.

53 Casas, De thesauris, pp. 198-199. Esta máxima está contenida tanto en el Codex como en el Digesto. Posteriormente fue retomada en la Edad Media dentro del contexto del derecho canónico. Es el Liber Sextus, del Corpus Iuris Canonici, el que cita Las Casas para retomar dicho principio, no obstante lo usa para hablar del gobierno secular. 
En distintas partes de su obra, principalmente en el tratado De regia potestate, aparecen claramente establecidos los actos o negocios en los cuales el gobernante necesitaba tener el consentimiento de la comunidad para llevarlos a cabo o que, en su defecto, pecaría y la acción no tendría valor jurídico. Entre otros asuntos destaca el establecimiento de nuevas leyes; ${ }^{54}$ la imposición, modificación o enajenación de cualquier tipo de tributo o impuesto $; 55$ la enajenación de bienes públicos, comunes y privados, ${ }^{56}$ y la enajenación, venta o

${ }^{54}$ Casas, De regia potestate, p. 81.

${ }_{55} \mathrm{Al}$ tratar sobre el problema de los impuestos en De regia potestate, Las Casas recupera gran parte de los argumentos constitucionalistas mencionados. Por esta razón me tomo la libertad de transcribir esta extensa cita: "Nunca se impuso sujeción ni servidumbre alguna ni carga sin que el pueblo que las iba a soportar consintiese voluntariamente en dicha imposición [...] Por tanto, si el pueblo fue la causa efectiva o eficiente y final de los reyes y los príncipes, puesto que tuvieron origen en el pueblo mediante una elección libre, no pudieron imponer al pueblo nunca más que los servicios y tributos que fuesen gratos al mismo pueblo y con cuya imposición consintiese libremente el pueblo [...] De donde se deduce claramente que al elegir al príncipe o rey el pueblo no renunció a su libertad ni le entregó o concedió la potestad de gravarle o violentarle o de hacer o legislar cosa alguna en perjuicio de todo el pueblo o de la comunidad. No fue necesario explicar esto cuando elegían al rey, porque lo que está implícito ni se argumenta ni se disminuye aunque no se diga expresa y declaradamente. Así, pues, se hizo necesario el consentimiento del pueblo para impedir que fuese gravado, privado de su libertad o la comunidad fuese violentada [...] Además, lo que tiene que aprovechar a todos o a todos puede perjudicar ha de hacerse con consentimiento de todos, por lo que se requiere el consentimiento de todos los hombres libres, es decir, de todo el pueblo, en asuntos de esa clase"; CASAs, De regia potestate, pp. 61-65. A lo largo de la cita Las Casas hace tres referencias a las Institutas, tres al Digesto y dos al Codex del derecho romano, así como una a las Decretales del derecho canónico.

${ }^{56}$ Con excepción de los bienes patrimoniales del gobernante, Casas, De regia potestate, pp. 101-103. 
permuta de la jurisdicción o el dominio de ciudades, villas o cualquier tipo de población a otra persona. ${ }^{57}$

¿Qué entendía Las Casas por el consentimiento o la voluntad del pueblo y cómo era posible acceder a ella? Recordemos que para Las Casas la comunidad se constituía en sociedad política como un solo cuerpo, cuya voluntad o último fin era el bien común. Dentro del pensamiento escolástico en general, una de las principales formas en que se manifestaba la voluntad de la comunidad era en sus usos y costumbres. Por esta razón, la costumbre tenía validez de ley y los gobernantes debían respetarla. ${ }^{58}$ Las Casas compartía este presupuesto, aunque consideraba otros mecanismos por los cuales debía expresarse el consentimiento del pueblo. Al tratar sobre los tributos explica otra forma mediante la cual la voluntad de la república debía ser conocida por las autoridades. El dominico sostenía que siempre que un pueblo libre es obligado a pagar una carga, "conviene que se convoque a cuantos el negocio atañe y que se obtenga su libre consentimiento, de lo contrario, lo actuado no tendrá valor alguno". ${ }^{99}$ Así, por ejemplo, si el rey de España quería legítimamente cobrar tributos a los indios, se requería que "todos los reyes y la universalidad de los pueblos de aquellas naciones sean convocados y que sea demandado y con

\footnotetext{
57 Casas, De regia potestate, p. 99.

58 Tanto los textos del derecho común y sus comentaristas como diversas fuentes teológicas concebían la costumbre como la voluntad tácita del pueblo y sostenían que tenía validez de ley. Las Casas refiere en diversas ocasiones al tema de la costumbre; entre otras, véanse CAsas, Doce dudas, p. 188; Regia potestate, p. 123.

59 Casas, Doce dudas, p. 69.
} 
seguido judicialmente de parte de ellos, su libre consenso". ${ }^{60}$ El hecho de que fuera necesario para el rey contar con el consentimiento judicial de los pueblos y sus gobernantes inmediatos nos habla de que Las Casas tenía en mente un mecanismo de validación de las acciones de gobierno riguroso y sofisticado que otorgara un amplio poder a las comunidades. ${ }^{61}$

Como vemos, aunque al tratar sobre los límites de la autoridad Las Casas recupera principios del iusnaturalismo tomista - al considerar el derecho natural como un referente objetivo para determinar la justicia de las acciones de gobierno-, el centro de su argumentación lo ocupa la voluntad del pueblo y los pactos con la autoridad emanados de ésta. En este punto Las Casas se distancia de los principales autores de la segunda escolástica, como Francisco de Vitoria, Domingo de Soto o Alonso de la Veracruz, quienes, a pesar de la importancia que le daban a la voluntad de la comunidad dentro del gobierno de la república, consideraban que los principios del derecho natural se encontraban por encima de ésta y eran el último referente para legitimar la acción de un gobernante. Las Casas, en cambio, situaba en el mismo nivel ambos elementos: tan necesario era que la acción política respetara los principios de la razón natural como que respetara las condiciones de gobierno establecidas por la república y contara con el libre consentimiento del pueblo en su conjunto.

${ }^{60}$ Casas, Doce dudas, p. 69; el mismo principio en Casas, De thesauris, pp. 197-201 y 211-213.

${ }_{61}$ Como se verá más adelante, Las Casas veía en la representación de las ciudades en Cortes y en los procuradores en Corte una de las formas de ejercicio de este poder. 


\section{LA LIBERTAD COMO NO DEPENDENCIA}

Para Las Casas la libertad es el bien más preciado que puede tener un pueblo. ${ }^{62}$ Por esta razón, como se señaló, el problema de cómo ser libres bajo el poder de un gobernante se ubica en el centro de su reflexión política. Al atender esta problemática, Las Casas utiliza el concepto de libertad de distintas formas. El uso que hace del concepto y el lugar que ocupa dentro de su pensamiento lo distinguirá de la mayor parte de los escolásticos de su tiempo y lo acercará a ciertos postulados desarrollados paralelamente por el humanismo cívico. Veamos cómo concibe el autor la libertad para después analizar las implicaciones que tenía en su teoría política.

Las Casas entiende la libertad de dos formas distintas, por un lado, como una facultad y un derecho natural del ser humano y, por otro, como un estado o situación. El primer uso del concepto, el más extendido entre los autores escolásticos de la época, concibe la libertad como la facultad individual, fundada en la razón, para tomar decisiones y proceder conforme a ellas dentro de un marco limitado por el derecho. Esta idea de libertad recupera principios del derecho romano, así como de la tradición aristotélica-tomista. Las Casas transcribe en varias de sus obras la definición que aparece en el Digesto, donde se presenta la libertad como "la facultad natural, esto es, la posibilidad de hacer aquello que a cualquiera le agrada hacer, salvo que la fuerza o el derecho se lo prohíba”. ${ }^{63}$ Ser libre, en este sentido, es poder

${ }^{62}$ Siguiendo al Digesto señala que "La libertad es más preciosa e inestimable que todas las riquezas que pueda tener un pueblo", CASAs, $D e$ regia potestate, p. 83.

${ }^{63}$ CASAs, De thesauris, p. 193. En otro lugar sostiene: "La libertad natural 
actuar - sin impedimentos de fuerza o de derecho- en la búsqueda de fines específicos. ${ }^{64}$ Cuando Las Casas atribuye esa facultad a la posesión del raciocinio remite a principios postulados por Aristóteles y Tomás de Aquino, quienes sostenían que el acto libre era necesariamente el resultado de un proceso deliberativo en el que intervenían la razón y la voluntad. Solo los hombres, en tanto seres racionales, podían elegir conscientemente entre distintas opciones para actuar dentro del campo que les era permitido por la fuerza o la ley en sus distintos niveles.

Esta libertad, para Las Casas, era dada a los hombres por naturaleza. Al argumentar esto, el dominico se oponía a la teoría aristotélica de la servidumbre natural, que sostenía que en el mundo había hombres que por naturaleza debían dominar a otros. Retomando principios del derecho romano, Las Casas sostenía que, desde su origen, todos los hombres eran libres, pues, por su condición racional, todos tenían la facultad de disponer sobre sí mismos, y no existía en la naturaleza la subordinación de una persona a otra. ${ }^{65}$ No obstante, siguiendo nuevamente los textos del

se define como facultad o sea capacidad natural de hacer lo que a cada uno le parece, excepto si lo prohíbe la fuerza o el derecho", CasAs, Doce dudas, p. 65. La misma definición aparece en CASAs, De regia potestate, p. 39. Recoge el principio del Digesto que señala: "Libertas est naturalis facultas eins quod cuique facere libet nisi si quid vi aut iure probibetur". ${ }^{64}$ Esta forma de concebir la libertad, definida luego en términos de ausencia de interferencia, se asocia fuertemente con la tradición política liberal. Si bien es cierto que es un elemento central del pensamiento liberal y que fue ampliamente desarrollada dentro de dicha tradición, adoptando otras formas e implicaciones, su formulación es anterior a ella, como queda claro en la cita anterior al derecho romano. Sobre este asunto véase SKINNER, Liberty before Liberalism, pp. 5-6.

${ }^{65}$ Señala: "Esto se demuestra porque nacen libres como consecuencia de 
derecho romano, reconocía que el ser humano había instituido mediante el derecho de gentes la esclavitud y la servidumbre, razón por la cual existían en el mundo hombres libres y siervos. ${ }^{66}$ Así, mientras la esclavitud era una institución jurídica creada por el hombre, un estado accidental que existía solo como resultado de una serie de condiciones establecidas previamente por los pueblos, la libertad era natural, en el sentido de intrínseca al ser humano, y por ello no podía ser coaccionada de forma injustificada por ninguna persona.

En sus últimos tratados Las Casas hará un movimiento singular al considerar esta forma de libertad como un derecho que le correspondía al ser humano por naturaleza. Así lo apuntaba al señalar que: "la libertad es un derecho ínsito en el hombre por necesidad y per se, como consecuencia de la naturaleza racional y, por ello, es de derecho natural" ${ }^{67} \mathrm{Al}$ hacer esto, Las Casas establecía una defensa más enfática de la libertad, pues mientras una facultad se podía o no ejercer, un derecho de esta naturaleza era imprescriptible. ${ }^{68}$

su naturaleza racional (Digesto). Como todos tienen la misma naturale$\mathrm{za}$, Dios no hace a uno siervo del otro, sino que concede a todos el mismo libre albedrío. Y la razón de ello es, según $\mathrm{S}$. Tomás, que la naturaleza racional, como es per se, no está ordenada a otra que sea su fin, como tampoco un hombre está ordenado a otro", CASAs, De regia potestate, p. 35. ${ }^{66}$ Casas, De regia potestate, pp. 37-39.

${ }^{67}$ Casas, De regia potestate, pp. 34-36.

${ }^{68}$ CASAs, De regia potestate, p. 45 . El concebir la libertad como un derecho era muy poco usual en la época. Que Las Casas pudiera hacerlo responde, a mi juicio, al incremento dentro del lenguaje escolástico del uso del concepto ius como derecho subjetivo, es decir, como algo que le pertenece a la persona y no como un marco objetivo ajeno a ella. Para el momento en que escribe Las Casas el desarrollo del concepto de derecho en su sentido subjetivo dentro de la Segunda Escolástica estaba muy avanzado. No obstante, hasta donde llega mi conocimiento, Las Casas, junto 
El uso del concepto de libertad en este sentido es fundamental en los escritos de Las Casas para denunciar la coacción injustificada a los indígenas americanos, y es a partir de él que el autor establece sus críticas a la encomienda, el repartimiento o el empleo de la fuerza para la evangelización. En tanto que los hombres poseían por naturaleza el derecho a la libertad no podían ser obligados a actuar en contra de su voluntad sin justificación. No obstante, bajo este principio de libertad, los hombres - pensemos de nuevo en los indígenas americanos - eran o podían ser tenidos por libres pese a no haber autorizado el poder político sobre ellos o pese a no tomar parte en las decisiones de su gobierno; bastaba que no fueran molestados ni en sus bienes ni en sus personas. ${ }^{69}$

Ante esta limitación, Las Casas se aproxima al concepto de libertad de otra manera, concibiéndolo no solo como una facultad sino también como un estado o situación de no dependencia o servidumbre. ${ }^{70}$ Ciertamente, el dominico no hace explícito su doble uso del término, pero la distinción queda clara cuando apunta que originalmente todas

con Vázquez de Menchaca, será uno de los primeros en definir la libertad como un derecho subjetivo. Es preciso estudiar este tema con mayor profundidad, sobre todo sus implicaciones en el ámbito político. Sobre la relación de la libertad como derecho en el ámbito religioso para Las Casas, véase VAldivia, Llamado a la misión pacífica. Sobre el desarrollo del concepto ius como derecho subjetivo dentro de la segunda escolástica véase BRETT, Liberty, Right and Nature.

${ }^{69}$ Este es precisamente el tipo de libertad reconocida a los indígenas en la famosa bula Sublimis Deus de 1537.

70 Este es el concepto de libertad republicano o neorromano estudiado con detenimiento en SKINNER, Liberty before Liberalism, y SKINNER, Hobbes y la libertad republicana. 
las tierras y los objetos, al no tener dueños, eran libres. ${ }^{71} \mathrm{Si}$ la libertad es entendida solo como la facultad de actuar, resultaría imposible que los objetos inanimados fueran libres; así pues, en este otro sentido, libertad significa no estar bajo la posesión o el dominio de alguien más.

Esta forma de concebir la libertad, a la cual Las Casas también accede mediante el derecho romano, es utilizada por el autor no solo para hablar de los objetos, sino también de los individuos y los pueblos en un contexto político. Al igual que las cosas, los hombres y las sociedades son libres al no estar sujetas a la voluntad arbitraria de un tercero, cuando no están en una situación de dominación o servidumbre. Por esta razón, los límites a la autoridad analizados en el apartado anterior resultaban necesarios para evitar la pérdida de libertad. Insistiendo en este punto, Las Casas hacía explícito el principio de que el gobernante no debía actuar según su arbitrio, sino siguiendo lo establecido por las leyes, las cuales debían estar subordinadas al bien común:

Ningún rector, rey o príncipe, de ningún reino o comunidad, por más alto que sea, tiene libertad o potestad de mandar a sus súbditos como quiera y al arbitrio de su voluntad, sino solo según las leyes.

Ahora bien, las leyes deben de estar redactadas para el bien común de todos y no en perjuicio de la república, sino ajustadas a la república y al bien público, y no la república a las leyes. $^{72}$

${ }^{71}$ Dice Casas: "todas las tierras y todas las cosas fueron libres y alodiales, esto es, francas y no sujetas a servidumbre, por derecho natural y de gentes", CASAS, De regia potestate, p. 35 .

72 Casas, De regia potestate, p. 85. 


\section{Y en otro lugar apunta:}

Quien manda tiene sobre sus súbditos una potestad no suya sino de la ley, que está subordinada al bien común, por lo que los súbditos no están bajo la potestad de quien manda, sino de la ley, ya que no están debajo de un hombre, sino de la ley justa. De lo que se deduce que, aunque los reyes tengan ciudadanos y súbditos, éstos no son plena y propiamente posesiones suyas. [Y concluye, tras citar a Séneca y Aristóteles:] De ello se deduce que el dominio (como impropiamente se llama) que reciben los reyes sobre sus reinos no implica ningún perjuicio a la libertad. ${ }^{73}$

Las Casas desarrolló en el contexto hispano postulados similares a los que desde algún tiempo atrás venían sosteniendo los defensores de las repúblicas italianas del Renacimiento. ${ }^{74} \mathrm{Al}$ igual que los autores del llamado humanismo cívico, el dominico ubicó la libertad en el centro de su filosofía política y describió al tirano no solo como el que gobernaba contra los principios del derecho natural sino, sobre todo, como aquel que atentaba contra la libertad de la comunidad. ${ }^{75}$ Para Las Casas la libertad como no dependencia también era de derecho natural y, por lo tanto, extensiva a todos los seres humanos. Así lo apuntaba al sostener que

73 Casas, De regia potestate, p. 67.

74 SKInNer, Liberty before Liberalism. Las ideas que comparte Las Casas con esta tradición incluyen, además de los dos principios antes mencionados, la defensa de la rotación temporal de cargos y oficios dentro de la república y su oposición a la venta de los mismos, aunque ciertamente el dominico no profundiza en ese punto; véase CASAs, De regia potestate, p. 139.

75 Casas, De regia potestate, p. 193. 
"desde los comienzos del género humano todos los hombres, todas las tierras y todas las cosas fueron libres y alodiales, esto es, francas y no sujetas a servidumbre, por derecho natural y de gentes". ${ }^{76}$

El principio de libertad como no servidumbre tenía, en el pensamiento de Las Casas, cuando menos dos implicaciones normativas: por un lado, la obligación de respetar la independencia de todas las naciones y pueblos de la tierra; y, por otro, la autonomía que dentro de una monarquía o imperio debían tener los individuos y los cuerpos políticos o repúblicas que éstos conformaban, particularmente las ciudades y, en el caso americano, los señoríos indígenas.

En cuanto a la primera implicación, Las Casas utiliza el concepto para denunciar las guerras e invasiones entre naciones y defender el derecho de los pueblos a gobernarse a sí mismos. En un momento en el que la noción de soberanía como hoy la entendemos no existía, ${ }^{77}$ Las Casas señalaba categóricamente que: "Cualesquier naciones y pueblos, por infieles que sean, poseedores de tierras y de reinos independientes, en los que habitaron desde un principio, son pueblos libres y no reconocen fuera de sí ningún superior, excepto los suyos propios". ${ }^{78}$

76 Casas, De regia potestate, p. 35. Como se señaló, para Las Casas el dominio - como propiedad, incluyendo a la servidumbre y la esclavitud - era una institución humana.

77 La formulación del concepto moderno de soberanía suele atribuírsele a Bodin y su consolidación se ubica a lo largo del siglo Xvir. La independencia de los pueblos del mundo - particularmente los infieles - era un tema polémico y discutido por los autores de la Baja Edad Media y la temprana modernidad.

78 Casas, "Principia quaedam", p. 1255. La misma idea en Doce dudas, p. 35 . 
Al sostener esto, argumentaba directamente contra los autores que, como Palacios Rubios o Ginés de Sepúlveda, consideraban legítimo dentro del marco del derecho natural y de gentes que una nación o persona interviniera para dominar a otra. Para Las Casas, los pueblos libres habían designado a sus propias autoridades y nadie más podía ejercer sobre ellos ningún tipo de poder o jurisdicción sin su consentimiento, sin importar que dicho gobierno no atentara contra los intereses de las comunidades en cuestión. La libertad, pues, en el contexto de las relaciones entre pueblos o naciones, se concebía como independencia. ${ }^{79}$

Para el autor, el simple temor a la pérdida de esta libertad daba a los pueblos el derecho de negar a personas extranjeras la entrada a su territorio. Al sostener esto, se oponía de forma directa a buena parte de los teólogos escolásticos, para quienes los hombres debían poder trasladarse por el mundo sin ser molestados. ${ }^{80}$ Apuntaba Las Casas:

79 Bajo este principio Las Casas construyó buena parte de sus argumen-
tos contra la conquista y dominación de las Indias. Para él, los reinos y
señoríos indígenas eran pueblos libres y, por lo tanto, independientes.
Ni los españoles, ni su rey, ni el emperador, ni el papa, podían ejercer
dominio sobre ellos sin su consentimiento, pues de lo contrario vivirían
en una situación de servidumbre y se atentaría contra su libertad. En este
punto, el pensamiento de Las Casas se distingue de la mayor parte de los
humanistas cívicos y otros autores republicanos que sostenían ideolo-
gías imperialistas. Sobre el carácter imperial del republicanismo, véanse
ARmiTAGe, "Empire and Liberty", y WEsTsTEIJn, "Republican Empire".
80 Estos autores remitían a principios del derecho de gentes como el
ius comunicandi o el ius peregrinandi, los cuales otorgaban a los hom-
bres el derecho a viajar, comerciar, predicar o explotar bienes no utiliza-
dos, siempre y cuando no afectaran a las personas que vivieran en dichas
tierras. Teólogos como Francisco de Vitoria o Alonso de la Veracruz
defendieron la validez de estos principios dentro de la discusión sobre 
Cualquier pueblo, ciudad, municipio o reino que no reconocen a otro príncipe superior, así como su sumo gobernador, pueden, mediante la promulgación de un estatuto o ley real, si ello fuera conveniente para la paz y tranquilidad, para evitar la corrupción de malas costumbres y para la defensa, seguridad y conservación del estado, reino o república, prohibir a toda persona del exterior, extranjera o de cualquier otro reino, la entrada a su reino, provincia o ciudad de su jurisdicción por el motivo que sea: para ejercer el comercio, cambiar, comprar, vender o fijar allí su residencia. Y actuar así sería obrar razonable y prudentemente, lo mismo se basaría en la autoridad del derecho de gentes y natural el castigar al que tratase de incumplir tales órdenes. [...] En efecto, todo pueblo libre, ciudad y comunidad razonablemente deben temer que otros más poderosos que ellos, de extraña nación, maquinen someterlos, con lo que perderían su libertad. ${ }^{81}$

La segunda implicación del concepto de libertad como ausencia de servidumbre, en la teoría de Las Casas se presenta, como se mencionó, en el terreno de la relación entre los reyes y los súbditos y los cuerpos políticos que éstos constituían. Recordemos que, para Las Casas, el rey no tenía el dominio - como derecho posesión - sobre sus súbditos sino

las Indias. Domingo de Soto, por su parte, adoptaría una postura similar a la de Las Casas.

${ }^{81}$ CASAs, De thesauris, pp. 149-151. Este principio lo sostiene para argumentar que todos los pueblos y señoríos indígenas pueden negar la entrada a sus tierras a los españoles. En los párrafos siguientes expone las razones del argumento y cierra ofreciendo autoridades que lo sostienen: distintas leyes del Códice, Digesto e Instituciones; el comentario de Bartolo sobre el Digesto, la obra de Andrés de Isernia, De probibita feudi alienatione, per Fredericum, y comentarios del mismo autor al Códice y Digesto, y el comentario de Baldo al Libri Feudorum. 
solo la jurisdicción para buscar el bien común, por lo tanto, el ejercicio del poder no debía implicar una relación de servidumbre que llevara a la pérdida de libertad de los gobernados. ${ }^{82}$ Así pues, no solo las naciones eran libres con relación a otras, también lo eran las comunidades con relación a su rey. Las Casas retomará este principio al hablar de las ciudades y, en el caso americano, de los pueblos y señoríos indígenas.

Recuperando principios del pensamiento aristotélico, Las Casas consideraba a la ciudad la comunidad perfecta, en tanto autosuficiente para la realización de la vida política y moral del hombre. ${ }^{83} \mathrm{Si}$ bien los seres humanos requerían de las ciudades para vivir, la existencia de las ciudades no dependía de formar parte de un reino. Su participación en una entidad más amplia era, entonces, por conveniencia. Por ello, al someterse libre y voluntariamente al poder de un rey o un emperador, las ciudades no debían perder su libertad ni

${ }^{82}$ En De regia potestate Las Casas sostiene que "la jurisdicción de los reyes solo tiene por finalidad procurar el bien común de los pueblos sin impedimento o perjuicio alguno de su libertad", LAS CASAS, De regia potestate, p. 67. Para explicar dicho principio señala que "Aunque los reyes tengan ciudadanos y súbditos, éstos no son plena y propiamente posesiones suyas. La posesión propiamente dicha significa que algo es totalmente de otro. De ello se deduce que el dominio (como impropiamente se llama) que reciben los reyes sobre sus reinos no implica ningún perjuicio a la libertad", CASAs, De regia potestate, 67. Remite el dominico a la autoridad de Aristóteles, Séneca y Tomás de Aquino.

83 Dice Las Casas: "Según Aristóteles, la ciudad es autosuficiente (Política; y Agustín, La ciudad de Dios). La define como un gran número de hombres unidos por un vínculo de convivencia que surge por la reunión de una multitud para convivir políticamente; en ella sus miembros se ayudan los unos a los otros, desempeñando cada uno un menester, y así es como la ciudad consigue su autosuficiencia y puede subvenir a sus necesidades independientemente de que forme parte del reino", CASAS, De regia potestate, p. 75 . 
sus gobernantes la autoridad que les había concedido el pueblo. En De regia potestate Las Casas se plantea la pregunta de si el rey puede obligar a las ciudades a ayudar al reino al que pertenecen cuando esto supone un riesgo para ellas. La respuesta para Las Casas es negativa:

La ciudad es parte del reino y siendo toda ciudad una comunidad perfecta y autosuficiente, cuya vida es su república según Aristóteles (Política), debe antes que nada mirar por todo lo que tiende a su defensa o conservación y, consiguientemente, no está obligada, para evitar algún mal o desgracia del reino o de alguna de sus partes, o para promover alguna utilidad o beneficio a los mismos, a exponerse a un peligro que pueda significar su destrucción o un daño grave. ${ }^{84}$

El lugar primordial que ocupaban las ciudades en la vida política no solo les otorgaba la capacidad de rechazar un mandato del rey sino que obligaba a éste a consultarlas para gobernar. El principio de la voluntad del pueblo como límite de la autoridad era también una manera por la cual las ciudades ejercían su libertad como autonomía. Las Casas encontraba en los mecanismos de las Cortes, instituciones en donde estaban representadas las ciudades de los reinos, y en los procuradores que solían mandar a la corte algunas poblaciones, una de las vías para hacerlo. ${ }^{85}$

${ }^{84}$ CASAs, De regia potestate, p. 71. En los siguientes párrafos profundiza en la idea, y citando al Digesto apunta que la ciudad es la patria del ciudadano y que este último tiene la obligación de obedecerla y luchar por defenderla. Así, el ciudadano debía dar la vida por su ciudad, pues de ella dependía su existencia, mas la ciudad no debía sacrificarse por el reino, pues su obligación era para con sus ciudadanos.

85 Señala el autor: "[...] ésta es la regla general, que el príncipe no puede 
Pero es en el tratamiento de los pueblos indígenas donde cobra más relevancia, dentro del pensamiento lascasiano, el uso del concepto de libertad como no dependencia. Como se señaló, Las Casas consideraba positivo que los señoríos indígenas americanos se incorporaran a la Monarquía española. Esto, para el dominico, facilitaría su conversión al cristianismo y su salvación. Sin embargo, acorde a su idea sobre el origen y la legitimidad del poder político, para que el rey de las Españas pudiera tener jurisdicción sobre los indígenas era absolutamente necesario contar con su consentimiento y el de los cuerpos políticos constituidos por ellos:

El hecho de aceptar a nuestro rey de las Españas como señor universal es algo que atañe a todas aquellas naciones de las Indias, no solo a los reyes y príncipes, pueblos, provincias, ciudades, municipios y lugares, sino también a cada persona de cada provincia, ciudad, municipio y lugar [...] Por lo tanto, siendo tales pueblos como son por naturaleza libres, por derecho natural gozan de la potestad y facultad de prestar su consentimiento y de contradecir. Luego todos, tanto grandes como pequeños, tanto los pueblos enteros como las personas individuales, deben ser convocados y de todos ellos deberá solicitarse y lograrse la presentación del libre consentimiento. ${ }^{86}$

hacer cosa en que venga perjuicio a los pueblos sin que los pueblos den su consentimiento, como vemos que Vuestra Majestad por su rectitud y justicia, siguiendo las pisadas de los Reyes Católicos, sus progenitores, hace cada día convocando a Cortes y mandando venir procuradores"; CASAs, Entre los remedios, p. 751. Para mayor información sobre las Cortes como espacios de negociación, véanse Fernández AlbalaDejo, Fragmentos de Monarquí, y ForteA, Monarquia y Cortes en la Corona de Castilla.

${ }^{86}$ CaSAS, De thesauris, p. 211-213. 
El consentimiento de los pueblos indígenas no se agotaba en la autorización de someterse a la jurisdicción del rey de España. Sí decidían finalmente incorporarse a la Monarquía, no podía esto implicar la pérdida de su libertad. Por ello, si el rey español se ubicaba como la autoridad suprema de una monarquía que incluyera los pueblos, reinos y señoríos indígenas, estaba obligado a respetar su libertad y sus propios gobiernos:

Conviene a saber que cuanto a la jurisdicción y gobierno general para los defender en sus estados y libertad, mayormente en las cosas de la fe, y cuanto a esto se dirán súbditos o vasallos suyos los reyes y los pueblos y vasallos, y los Reyes de Castilla se nombrarán Príncipes o Señores universales; pero cuanto al inmediato gobierno y jurisdicción sobre sus propios súbditos [los señores indígenas] no se pueden decir súbditos de los Reyes de Castilla [...] porque si lo que la objeción pretende se hubiese de entender y ejecutar, es manifiesto que con efecto era privar a los reyes de sus estados y vasallos y a los unos y a los otros de sus bienes y libertad, lo cual queda arriba reprobado, y como injusto y tiránico y abominado. ${ }^{87}$

El proyecto de Monarquía de Bartolomé de Las Casas contemplaba la idea de una especie de confederación de repúblicas libres en la que el rey ejercía la autoridad superior, limitada por las leyes y la voluntad de los pueblos y ciudades, y en donde los súbditos y las comunidades, particularmente los pueblos indígenas, conservaban sus propias jurisdicciones, mantenían su libertad como no dependencia.

87 Casas, Doce dudas, p. 209. La misma idea en p. 211. 


\section{CONCLUSIÓN}

En su reflexión sobre el problema de la incorporación de las Indias a la Monarquía hispánica y en su análisis de las características del poder regio, Las Casas buscó establecer los mecanismos para conciliar la libertad de los súbditos y el poder del rey. Al hacerlo, recuperó y desarrolló presupuestos y postulados políticos que podrían caracterizarse como republicanos y constitucionalistas. Entre ellos destacan el origen popular del poder de los gobernantes, la supremacía del bien común sobre los intereses particulares, la necesidad de limitar la autoridad mediante pactos y contratos, la exigencia de la participación del pueblo en su gobierno, y la defensa de la libertad como independencia de los hombres y las comunidades políticas.

Los principios utilizados por Las Casas aparecen también esgrimidos por autores de otras tradiciones, quienes, desde diversos lugares, momentos e intenciones, recurrieron a ellos para argumentar en sus propios contextos polémicos. Tal es el caso del humanismo cívico italiano, del republicanismo anglófono de mediados del siglo Xvir y de una serie de pensadores que participó en las revoluciones atlánticas de fines del siglo XVIII y principios del XIX. La diferencia entre cada una de estas tradiciones - caracterizadas como republicanas o constitucionalistas - no está entonces en haber recurrido a tales principios sino en la forma particular en que los integraron a sus discursos, en el uso que les dieron y, sobre todo, en las polémicas concretas en las que buscaron incidir.

Como se ha visto a lo largo de este artículo, Bartolomé de Las Casas recuperó y desarrolló dichos presupuestos dentro 
del lenguaje escolástico, partiendo de postulados aristotélicos, del iusnaturalismo tomista y del derecho común. A partir de ellos, sin desafiar el régimen monárquico, estableció una defensa de la libertad política de los pueblos, especialmente de los indígenas americanos. Al hacerlo, el dominico actualizó y ensanchó las posibilidades de uso e interpretación de algunos presupuestos constitucionalistas y republicanos de su tiempo. El lugar central que ocupó dentro de su lenguaje escolástico el concepto de libertad como no dependencia y el utilizar dichos argumentos para realizar una crítica a la dominación imperial sobre pueblos no europeos, serían características singulares de su pensamiento.

Más allá de mostrar la particularidad del pensamiento de Las Casas, probar que este autor pudo recuperar y actualizar estos recursos argumentativos, ampliando los límites de su interpretación, contribuye a revelar que la diversidad de los lenguajes políticos en Hispanoamérica fue mayor de lo que se suele reconocer para la modernidad temprana, que se pudo decir - y hacer - más de lo que comúnmente se ha pensado. Así, por ejemplo, se muestra que las teorías y prácticas de gobierno de carácter absolutista no fueron puestas en cuestión exclusivamente desde afuera, por tradiciones lejanas temporal o geográficamente. Como queda claro en los tratados de Las Casas, las críticas a los presupuestos y conceptos que defendían el poder absoluto de los reyes o que dejaban a la república fuera de los asuntos políticos, se pudieron establecer desde los métodos y las fuentes más comunes del mundo hispánico del siglo xvi; y, también es patente que no fueron hechas solo por autores marginales o clandestinos, sino que se establecieron desde el corazón mismo de la Monarquía. 
Si aceptamos lo anterior, es decir, que las condiciones de posibilidad del pensamiento de Las Casas y los recursos lingüísticos e intelectuales que tuvo a su disposición no fueron excepcionales, es posible reconocer la existencia de lenguajes republicanos hispanoamericanos desde el siglo Xvi. Estos lenguajes - en plural- se presentarían, no como tradiciones cerradas o acabadas, sino como conjuntos de conceptos, argumentos y presupuestos políticos disponibles para ser utilizados. ${ }^{88}$ Con ello, me parece, se podrían realizar nuevas lecturas del pensamiento político del mundo hispánico y, también, de las instituciones, prácticas y procesos políticos de la Monarquía. Pensemos, por mencionar unos ejemplos, en la vasta producción de tratados escolásticos sobre temas políticos y jurídicos; en los discursos elaborados por las ciudades y sus cabildos para dirigirse a la corona; en las formas que guardaron los constantes procesos de negociación que, en materia fiscal, se presentaron entre el rey y los cuerpos que conformaban los reinos; en los argumentos usados por los habitantes de las ciudades y los reinos para exigir ocupar los cargos políticos de su demarcación; o en la manera en que se organizó el gobierno de los indígenas a partir de las llamadas repúblicas de indios. ¿ Hasta qué punto presupuestos y argumentos similares a los que utilizó Las Casas en sus tratados aparecen desperdigados en estos y otros espacios de conflicto y negociación? Mi respuesta es que, una vez que se hacen visibles, que se considera la posibilidad de su formulación, resultan más comunes de encontrar de lo que probablemente asumiríamos.

${ }^{88}$ Un lenguaje político en un sentido amplio, como lo concibe Pocock, "El concepto de lenguaje". 


\section{REFERENCIAS}

Aguilar, José Antonio

En pos de la quimera. Reflexiones sobre el experimento constitucional atlántico, México, Fondo de Cultura Económica, Centro de Investigación y Docencia Económicas, 2000.

“Dos conceptos de república”, en Aguilar y Rojas, 2002, pp. 57-85.

Aguilar, José Antonio y Rafael Rojas (coords.)

El republicanismo en Hispanoamérica. Ensayos de historia intelectual y política, México, Fondo de Cultura Económica, Centro de Investigación y Docencia Económicas, 2002.

Alexander, Larry (ed.)

Constitutionalism. Philosophical Foundations, Cambridge, Cambridge University Press, 2001.

Annino, Antonio

“El primer constitucionalismo mexicano, 1810-1830", en Carmagnani, Hernández y Romano (coords.), 1999, pp. 140-189.

Aranda Pérez, Francisco José y José Damião Rodrigues (eds.)

De Re Publica Hispaniae. Una vindicación de la cultura política en los reinos ibéricos en la primera modernidad, Madrid, Sílex, 2008.

Armitage, David

"Empire and Liberty: A Republican Dilema”, en VAN GELdeREN y SKINNER, 2002, vol. 2, pp. 29-46.

Astudillo, César y Jorge Carpizo

“Presentación”, en Astudillo y Carpizo (coords.), 2013, pp. xi-xvi. 
Astudillo, César y Jorge Carpizo (coords.)

Constitucionalismo. Dos siglos de su nacimiento en América Latina, México, Universidad Nacional Autónoma de México, Instituto Iberoamericano de Derecho Constitucional, 2013.

Ávila, Alfredo

"Pensamiento republicano hasta 1823", en Aguilar y Rojas, 2002, pp. 313-350.

Ball, Terence, James Farr y Russell Hanson

Political Innovation and Conceptual Change, Cambridge, Cambridge University Press, 1995.

Bataillon, Marcel

Estudios sobre Bartolomé de Las Casa, Barcelona, Península, 1976.

Belda Plans, Juan

La Escuela de Salamanca y la renovación de la teología en el siglo XVI, Madrid, Biblioteca de Autores Cristianos, 2000.

Beuchot, Mauricio

Los fundamentos de los derechos humanos en Bartolomé de Las Casas, Barcelona, Anthropos, 1994.

Bocardo Crespo, Enrique (ed.)

El giro contextual. Cinco ensayos de Quentin Skinner y seis comentarios, Madrid, Tecnos, 2007.

BretT, Annabel

Changes of State. Nature and the Limits of the City in Early Modern Natural Law, Princeton, Princeton University, 2011. Liberty, Right and Nature. Individual Rights in Later Scholastic Thought, Cambridge, Cambridge University Press, 2003. 
Burns, J. H.

Lordship, Kingship, and Empire: The Idea of Monarchy 14001525, Oxford, Clarendon Press, 1992.

Cañeque, Alejandro

The King's Living Image. The Culture and Politics of Viceregal Power in Colonial Mexico, Nueva York, Routledge, 2004.

Cárdenas Bunsen, José Alejandro

Escritura y derecho canónico en la obra de fray Bartolomé de Las Casas, Madrid, Iberoamericana, Vervuert, 2011.

Cardim, Pedro

"La jurisdicción real y su afirmación en la corona portuguesa y sus territorios ultramarinos (siglos XVI-XVIII)", en ArAnDA y Rodrigues, 2008, pp. 349-388.

Cardim, Pedro, Tamar Herzog, Javier Ruiz Ibáñez y Gaetano Sabatini (eds.)

Polycentric Monarchies. How Did Early Modern Spain and Portugal Achieve and Maintain a Global Hegemony?, Sussex, Sussex Academic Press, 2012.

Carmagnani, Marcelo, Alicia Hernández y Ruggiero Romano (coords.)

Para una historia de América III. Los nudos (2), México, Fondo de Cultura Económica, Fideicomiso Historia de las Américas, El Colegio de México, 1999.

CAsas, Bartolomé de Las

De thesauris, Madrid, Alianza, 1992.

Doce dudas, Madrid, Alianza, 1992.

De regia potestate. Quaestio theologalis, Madrid, Alianza, 1990.

“Principia quaedam”, en CAsAs, 1965, vol. II, pp. 1234-1273.

“Entre los remedios”, en CAsas, 1965, vol. II, pp. 643-851. 
Tratados, México, Fondo de Cultura Económica, 1965.

Apologética historia sumaria, México Universidad Nacional Autónoma de México, 1967.

Centenero, Domingo

De repúblicas urbanas a ciudades nobles: un análisis de la evolución y desarrollo del republicanismo castellano (1550-1621), Madrid, Biblioteca Nueva, 2012.

Chust, Manuel e Ivana Frasquet

"Orígenes federales del republicanismo en México" en Mexican Studies/ Estudios Mexicanos, 24:2 (2008), pp. 363-398.

Clavero, Bartolomé

Tantas personas como estados. Por una antropología política de la historia europea, Madrid, Tecnos, 1986.

ElLiotT, John H.

España, Europa y el mundo de ultramar (1500-1800), México, Taurus, 2010.

"Una Europa de monarquías compuestas", en Elliot, 2010, pp. 29-54.

Fernández Albaladejo, Pablo

Fragmentos de Monarquí: trabajos de historia política, Madrid, Alianza, 1992.

ForTEa, José Ignacio

Monarquía y Cortes en la Corona de Castilla. Las ciudades ante la politica fiscal de Felipe II, Valladolid, Cortes de Castilla y León, 1990.

Fortea, José Ignacio y Juan E. Gelabert (coords.)

Ciudades en conflicto (siglos XVI-XVIII), Valladolid, Junta de Castilla y León, Marcial Pons, 2008. 
García, Eloy

"Estudio preliminar. Una propuesta de relectura del pensamiento político: John Pocock y el discurso republicano cívico”, en Poсоск, 2002, pp. 9-73.

García del Corral, Idelfonso

Cuerpo del derecho civil romano, Barcelona, Jaime Molinas, 1889.

García García, Emilio

“Bartolomé de Las Casas y los derechos humanos”, en MACEIRAS y MÉndez, 2011, pp. 81-114.

Garriga, Carlos

"Continuidad y cambio del orden jurídico", en Garriga (coord.), 2010, pp. 59-106.

“Orden jurídico y poder político en el Antiguo Régimen”, en Istor. Historia y derecho, historia del derecho, IV: 16 (2004), pp. 13-44.

Garriga, Carlos (coord.)

Historia y Constitución. Trayectos del constitucionalismo hispano, México, Centro de Investigación y Docencia Económicas, El Colegio de México, El Colegio de Michoacán, Escuela Libre de Derecho, Proyecto de Investigaciones Hicoes, Universidad Autónoma de Madrid, 2010.

Gascón Pérez, Jesús

"Los fundamentos del constitucionalismo aragonés. Una aproximación”, en Manuscrits: Revista d'bistòria moderna, 17 (1999), pp. 253-275.

Gil Pujol, Xavier

Las claves del Absolutismo y el Parlamentarismo, 1603-1715, Barcelona, Planeta, 1991. 
"Ciudadanía, patria y humanismo cívico en el Aragón foral: Juan Costa", en Manuscrits: Revista d'bistòria moderna, 19 (2001), pp. 81-101.

"Republican Politics in Early Modern Spain: The Castilian and Catalano-Aragonese Traditions", en Van Gelderen y Skinner, 2002, vol. i, pp. 263-288.

"Constitucionalismo aragonés y gobierno Habsburgo: los cambiantes significados de libertad”, en KAGAN y PARKer (eds.), 2001, pp. 217-249.

Grossi, Paolo

Elorden jurídico medieval, Madrid, Marcial Pons, 1996.

Hanke, Lewis

“Bartolomé de Las Casas, historiador”, en Casas, 1951, pp. ix-lxxxviii.

Hanke, Lewis y Manuel Giménez Fernández

Bartolomé de Las Casas, 1474-1566: Bibliografía crítica y cuerpo de materiales para el estudio de su vida, escritos, actuaciones y polémicas que se suscitaron durante cuatro siglos, Santiago de Chile, y Fondo Histórico y Bibliográfico José Toribio Medina, 1954.

Hardin, Russell

Liberalism, Constitutionalism, and Democracy, Oxford, Oxford University Press, 1999.

Hespanha, Antonio Manuel

Cultura jurídica europea. Sintesis de un milenio, Madrid, Tecnos, 2002.

Visperas de Leviatán, instituciones y poder político (Portugal, siglo XVII), Madrid, Taurus, 1989.

Howard, Charles

Constitutionalism: Ancient and Modern, Ithaca, Cornell University Press, 1947. 
Kagan, Richard L. y Geoffrey Parker (eds.)

España, Europa y el mundo atlántico: homenaje a John $H$. Elliott, Madrid, Marcial Pons, Junta de Castilla y León, Consejería de Educación y Cultura, 2001.

KeLLY, Donald

"Civil science in the Renaissance: The Problem of Interpretation”, en Pagden, 1987, pp. 57-78.

La Torre, Massimo

"Constitucionalismo de los antiguos y de los modernos. Constitución y 'estado de excepción'”, en Res Publica, 23 (2010), pp. 17-35.

Luna, Adriana, Pablo Mijangos y Rafael Rojas (coords.)

De Cádiz al siglo XXI. Doscientos años de constitucionalismo en México e Hispanoamérica (1812-2012), México, Taurus, 2012.

Maceiras, Manuel y Luis Méndez (coords.)

Los Derechos Humanos en su origen. La República Dominicana y Antón de Montesinos, Salamanca, San Esteban, 2011.

Maddox, Graham

“Constitution”, en Ball, Farr y Hanson, 1995, pp. 50-67.

Marcano, Enrique

"Del republicanismo clásico al republicanismo moderno. Juan de Mariana y la tradición republicana”, en PeÑa, 2000, pp. 127-165.

Mazín, Óscar y José Javier Ruiz Ibáñez (eds.)

Las Indias Occidentales. Procesos de incorporación territorial a las Monarquias Ibéricas, México, El Colegio de México, 2012. 
NAIR, Harikrishnan

"Contra imperio: el discurso de derecho natural y la autonomía de los indios americanos", tesis de doctorado en historia, México, Universidad Nacional Autónoma de México, 2010.

Pagden, Anthony (ed.)

The Languages of Political Theory in Early-Modern Europe, Cambridge, Cambridge University Press, 1987.

Palacios Bañuelos, Luis e Ignacio Ruiz Rodríguez (dirs.)

Cádiz 1812. Origen del constitucionalismo español, Madrid, Dykinson, 2013.

PAlti, Elías

La invención de una legitimidad: razón y retórica en el pensamiento mexicano del siglo XIX (un estudio sobre las formas del discurso político), México, Fondo de Cultura Económica, 2005.

"Las polémicas en el liberalismo argentino. Sobre virtud, republicanismo y lenguaje", en Aguilar y Rojas (coords.), 2002, pp. 167-209.

PAni, Erika

"Maquiavelo en el septentrión. Las posibilidades del republicanismo en Hispanoamérica”, en Prismas, 13 (2009), pp. 295-300.

PARISH, Helen-Rand

Las Casas as a Bishop: A New Interpretation Based on His Holograph Petition in the Hans P. Kraus Collection of Hispanic American Manuscripts, Washington, Library of Congress, 1980.

Pena González, Miguel Anxo

La Escuela de Salamanca. De la Monarquía hispánica al Orbe católico, Madrid, Biblioteca de Autores Cristianos, 2009.

Pennington, Kenneth

"Bartholome de Las Casas and the tradition of Medieval Law”, en Church History, 39: 2 (1970), pp. 149-161. 
PeÑA, Javier

Poder y modernidad. Concepciones de la política en la España moderna, Salamanca, Universidad de Valladolid, 2000.

Pereña, Luciano

Carta magna de los indios. Fuentes constitucionales, 15341609, Madrid, Consejo Superior de Investigaciones Científicas, 1988.

Pettit, Philip

Republicanism: A Theory of Freedom and Government, Oxford, Oxford University Press, 1997.

Pietschmann, Horst

“El primer constitucionalismo en México o ¿cómo configurar una realidad colonial de antiguo régimen para un futuro en el marco de una nación republicana? Introducción a un trabajo de seminario de investigación”, en Jabrbuch für Geschichte Lateinamerikas, 42 (2005), pp. 235-242.

Pocock, John

El momento maquiavélico. El pensamiento político florentino y la tradición republicana atlántica, Madrid, Tecnos, 2002.

Pensamiento politico e historia. Ensayos sobre teoría y método, Madrid, Akal, 2009.

"El concepto de lenguaje y el metier d'historien: reflexiones en torno a su ejercicio", en Poсоск, 2009, pp. 101-118.

Queraltó Moreno, Ramón

El pensamiento filosófico-político de Bartolomé de Las Casas, Sevilla, Escuela de Estudios Hispano-Americanos, 1976.

Rodgers, Daniel T.

"Republicanism: the Career of a Concept", en The Journal of American History, 79:1 (1992), pp. 11-38. 
Rojas, Rafael

Las repúblicas de aire. Utopía y desencanto en la revolución de Hispanoamérica, México, Taurus, 2009.

"La frustración del primer republicanismo mexicano", en Aguilar y Rojas (coords.), 2002, pp. 388-423.

Rubies, Joan Pau

"La idea del gobierno mixto y su significado en la crisis de la Monarquía Hispánica”, en Historia Social, 24 (1996), pp. 57-81.

"Reason of State and Constitutional Thought in the Crown of Aragon, 1580-1640", en The Historical Journal, 38: 1 (1995), pp. 1-28.

Ruiz Ruiz, Ramón

"El republicanismo clásico en el pensamiento hispano: comentarios sobre una tradición frustrada", en Anales de la Cátedra Francisco Suárez, 47 (2013), pp. 273-297.

SkINNER, Quentin

Los fundamentos del pensamiento político moderno, México, Fondo de Cultura Económica, 1993.

Liberty before liberalism, Cambridge, Cambridge University Press, 1998.

Hobbes y la libertad republicana, Buenos Aires, Universidad Nacional de Quilmes, Prometeo 3010, 2010.

Visions of Politics. Volume 2. Renaissance Virtues, Cambridge, Cambridge University Press, 2002.

"Significado y comprensión en la historia de las ideas", en BoCARDO, 2007, pp. 66-76.

“The rediscovery of republican values", en SKInNER, 2002, pp. 10-38.

Thomson, Irving A. A.

Guerra y decadencia. Gobierno y administración en la España de los Austrias, 1560-1620, Barcelona, Crítica, 1981. 
Tierney, Brian

Religion, Law, and the Growth of Constitutional Thought 1150-1650, Cambridge, Cambridge University Press, 1982.

Utrera García, Juan Carlos

Conciliarismo y constitucionalismo. Selección de textos I. Los orígenes del pensamiento constitucionalista, Barcelona, Marcial Pons, 2005.

VAldivia Giménez, Ramón

Llamado a la misión pacífica: la dimensión religiosa de la libertad en Bartolomé de las Casas, Sevilla, Consejo Superior de Investigaciones Científicas, Universidad de Sevilla, 2010.

Van Gelderen, Martin y Quentin Skinner

Republicanism. A Shared European Heritage, Cambridge, Cambridge University Press, 2002.

“Introduction”, en VAN GELdEREN y SKINNER, 2002, vol. I, pp. 1-6.

Varela Suanzes-Carpegna, Joaquín

La teoría del Estado en los orígenes del constitucionalismo hispánico (Las Cortes de Cádiz), Madrid, Centro de Estudios Constitucionales, 1983.

Velasco, Ambrosio

Republicanismo y multiculturalismo, México, Siglo Veintiuno Editores, 2006.

Villacañas Berlanga, José Luis

"Republicanismo clásico en España: las razones de una ausencia”, en Journal of Spanish Cultural Studies, 6:2 (jul. 2005), pp. 163-183.

Weststeijn, Arthur

"Republican Empire: Colonialism, Commerce and Corruption in the Dutch Golden Age”, en Renaissance Studies, 26:4 (2012), pp. 491-509. 